\title{
Global health diplomacy: a 'Deus ex Machina' for international development and relations
}

\author{
Comment on "A Ghost in the Machine? Politics in Global Health Policy"
}

\section{Sebastian Kevany ${ }^{\star}$}

Correspondence to: Sebastian Kevany, Email: sebastian.kevany@ucsf.edu Copyright: () 2014 by Kerman University of Medical Sciences Citation: Kevany S. Global health diplomacy: a 'Deus ex Machina' for international development and relations; Comment on "A Ghost in the Machine? Politics in Global Health Policy". Int JHealth Policy Manag 2014; 3: 111-112. doi: 10.15171/ijhpm.2014.67 Received: 7 July 2014, Accepted: 23 July 2014, ePublished: 27 July 2014

$\mathrm{B}$ rugha and Bruen (1) raise a number of compelling issues related to the interaction between politics and policy in the global health context. The first question that their views invite is whether this is, at heart, best characterized as a benign or malign influence. Many commentators have suggested that this overlap should be discouraged (2-4), while others advocate a decrease in 'stove-piped' or 'siloed' approaches to government, politics, and academia $(5,6)$. To use a parallel example, the world of sport has indirectly contributed a number of notable political advances, not least the end of apartheid in South Africa as a partial result of the ban imposed on their international teams (7). In spite of this, organizations such as FIFA refuse to be drawn into supporting sanctions against international football teams on non-sporting grounds (8). The future scope and role of global health will, inevitably, face corresponding challenges. In this context-and in terms of the sustainability of global health funding in a time of fiscal austerity-an enhanced role for political considerations may be just the "Deus ex Machina" that global health needs.

Diplomacy in global health leadership The authors point to global health leaders such as Sir Richard Feachem as necessarily being adept at both political machinations as well as the more altruistic goals of international health and development. Organizations such as the World Bank, the Global Fund to Fight AIDS, Tuberculosis and Malaria, and the World Health Organization (WHO), and their leaders, are increasingly aware of their responsibilities in this context $(9,10)$; for example, the damage done to international relations through deeply unpopular structural adjustment policies of the late $20^{\text {th }}$ Century (11) are, fortunately, now a thing of the past. In the $21^{\text {st }}$ Century, global health leaders will be drawn from a more dynamic, interdisciplinary and, above all, diplomatic generation (12).

The formalization of political considerations in global health

Bruen and Brugha refer to the 'ghost in the machine' of politics in global health. This reflects the traditionally implicit, yet undefined, role of political considerations in this context. Institutions such as the WHO have been implicitly politicised since their inception (13), and contemporary global health initiatives find their roots in colonial and post-colonial political and economic considerations (13). Increasingly, in the $21^{\text {st }}$ Century, such influences are formalised and explicit. This evolution has been led by the creation of the Office of Health Diplomacy in the United States Department of State, which has been mandated with an official agenda to optimise the diplomatic and foreign policy impact of global health programmes (14). The European Union has enshrined the use of global health programmes as part of its external relations 'soft power' strategy (15), while the United Kingdom has recognised the pursuit of international affairs goals as a central responsibility—even raison d'etre-of the Department for International Development (16).

\section{Tempering extremist donor approaches}

In the recent Ugandan parliament ruling outlawing homosexuality (17), both sides of the political spectrum in donor countries such as the United States considered each other culpable. Proponents of liberal and progressive sexual policies in the global health context accused the evangelical right of a focus on abstinence-only programmes, to the detriment of health services for "most at risk populations", (18); in response, conservative commentators countered with suggestions that policies acceptable in places such as San Francisco, driven by the 'unruly melange' of a highly effective local civil society (19), were imposed upon recipient countries without appropriate recognition of contemporary social, political, and cultural norms (20). In reality, the truth most likely lies somewhere between these two viewpoints. What is clear in both cases is that global health programmes, driven by either conservative or progressive political agendas, increasingly need to be monitored and vetted based on transcendent ideals that resonate with all elements of the political spectrum; the 'post-partisan' criteria of global health diplomacy. To paraphrase Rudyard Kipling, this will allow policy-makers to legislate and plan for the inevitable triumphs and disasters of programme implementation - but, ensured of diplomatic sensitivity, to treat these two imposters just the same.

Global health diplomacy and the Global Fund

Specific mention of the roles, aspirations, and responsibilities of the Global Fund in this context recognizes the innovative 
style of the organisation highlighted by Bruen and Brugha. The hidden, unmeasured, and collateral effects of Global Fund programmes in contexts such as Iraq and Afghanistan have been documented by this author elsewhere $(21,22)$. As the Global Fund may therefore help to bring much more than just good health to recipients, especially in conflict and post-conflict settings, should not such achievements be measured, documented, and brought to the attention of the Fund's (often sceptical) donors? In parallel, on the micro level, the responsibilities of local funding agents and fund portfolio managers in the international relations context are increasingly under scrutiny (23). The adversarial culture by which it has been suggested the Global Fund was initially driven (24) has been tempered by such 'neo-utilitarian' approaches" (25).

\section{Conclusion: formalizing the God in the machine}

In times of fiscal austerity, illustrating that political, foreign policy, diplomatic, or international relations ends can be achieved through global health, provides a "miraculous" (or "Deus ex Machina") added incentive to funders to maintain (or increase) their support of related bilateral and multilateral initiatives. The enhanced role of diplomacy and foreign policy in global health, therefore, has benign implications for global health funding, but also for world peace, for a new and less destructive role of military forces, and for both the theory and practise of international relations $(21,22)$. To date, the integration of such principles has been a largely ad-hoc process; terra incognita for both diplomats and global health practitioners. The development and application of explicit criteria for global health programme design, evaluation, and delivery from the diplomatic and foreign policy perspectives, both to optimise benign effects and to eliminate interdisciplinary threats (26), will help to usher in a new era for both global health and international relations-one in which the two disciplines will become inextricably linked.

\section{Ethical issues}

Not applicable.

\section{Competing interests}

Author declares that he has no competing interests.

\section{Author's contribution}

SK is the single author of the manuscript.

\section{References}

1. Bruen C, Brugha R. A Ghost in the Machine? Politics in Global Health Policy. Int J Health Policy Manag 2014; 3: 1-4. doi: 10.15171/ijhpm.2014.59

2. Thomas C, Weber M. The Politics of Global Health Governance: Whatever Happened to "Health for All by the Year 2000"? Global Governance: A Review of Multilateralism and International Organizations 2004; 10: 187-205.

3. Marseille E, Khan J. HIV prevention before HAART in subSaharan Africa. Lancet 2002; 359: 1851-6. doi: 10.1016/S01406736(02)08705-6

4. Fidler D. The Rise and Fall of Global Health as a Foreign Policy Issue. Global Health Governance 2011; 4: 10-8.

5. Lee K, Novotny T. Brazil and the Framework Convention on Tobacco Control: Global Health Diplomacy as Soft Power. PLoS Med 2011; 7: e1000232. doi: 10.1371/journal.pmed.1000232

6. Feldbaum $\mathrm{H}$, Michaud J. Health diplomacy and the enduring relevance of foreign policy interests. PLoS Med 2010; 7: e1000226. doi: 10.1371/journal.pmed.1000226

7. Nixon R. Apartheid on the Run: The South African Sports Boycott. Transition 2002; 58: 68-88.

8. Sobolev I, Gazeta R. FIFA turns down U.S. request to ban Russia from hosting the 2018 World Cup. Russia Beyond the Headlines News Website [internet]. 2014. Available from: http://rbth.com/ news/2014/04/06/fifa_turns_down_us_request_to_ban_russia_ from_hosting_the_2018_world_cup_35 $50303 . \mathrm{htm} \overline{\mathrm{l}}$

9. World Health Organization ( $\overline{\mathrm{W}} \mathrm{HO})$. Global Health Diplomacy [internet]. 2014. Available from: http://www.who.int/trade/ diplomacy/en/

10. Kevany S. International access and global health diplomacy in Sudan. The Lancet Global Health Blog [internet]. 2014. Available from: http://globalhealth.thelancet.com/2014/05/02/internationalaccess-and-global-health-diplomacy-sudan

11. Abouharb M, Cingranelli D. The Human Rights Effects of World Bank Structural Adjustment, 1981-2000. Int Stud Q 2006; 50: 233-62. doi: 10.1111/j.1468-2478.2006.00401.x

12. Katz R, Kornblet S, Arnold G, Lief E, Fischer J. Defining health diplomacy: Changing demands in the era of globalization. Milbank Q 2011; 89: 503-23. doi: 10.1111/j.1468-0009.2011.00637.x

13. Farmer P. Colonial Roots of Global Health. Harvard College Global Health Review [internet]. 2009. Available from: http:// hcghr.wordpress.com/2009/09/19/colonial-roots-of-global-health/

14. United States Department of State. About the Office of Global Health Diplomacy [internet]. 2014. Available from: http://www. state.gov/s/ghd/about/

15. Europa. Foreign and security policy: speaking with one voice. European Union policy document [internet]. 2010. Available from: http://www.europa.eu/pol/cfsp/index_en.htm

16. United Kingdom Foreign and Commonwealth Office. What we do [internet]. 2013. Available from: https://www.gov.uk/government/ organisations/foreign-commonwealth-office/about

17. The Guardian News Service. Ugandan MPs rush through draconian laws against homosexuality. The Guardian [serial on the internet]. 2013. Available from: http://www.theguardian.com/ world/2013/dec/20/uganda-mps-laws-homosexuality

18. Bailey S. U.S. Evangelicals Forced On The Defensive Following Uganda's Anti-Gay Laws [internet]. 2013. Available from: http:// www.huffingtonpost.com/2014/03/07/us-evangelicals-gaylaws_n_4899418.html

19. Buse K, Walt G. An unruly mélange? Coordinating external resources to the health sector: A review. Soc Sci Med 1997; 45: 449-63.

20. Weigratz J. Rejecting the West on policy: Uganda, neoliberalism and the Anti-Homosexuality Bill [internet]. 2014. Available from: http://africanarguments.org/2014/04/30/rejecting-the-west-onpolicy-uganda-neoliberalism-and-the-anti-homosexuality-bill-byjorg-wiegratzl

21. Kevany S, Jaf P, Workneh NG, Dalo MA, Tabena M, Rashid S, Al Hilfi TKY. Global health diplomacy in Iraq: International relations outcomes of multilateral tuberculosis programmes. Medicine, Conflict and Survival 2014; 30: 91-109. doi: 10.1080/13623699.2014.890827

22. Kevany S, Sahak O, Workneh NG, Saeedzai SA. Global health diplomacy investments in Afghanistan: Adaptations and outcomes of global fund malaria programs. Medicine, Conflict and Survival 2014; 30: 37-55. doi: 10.1080/13623699.2014.874187

23. Garmaise D. Global Fund Takes Steps to Improve LFA Performance. AIDSPAN Newsletter [serial on the internet]. 2011. Available from: http://www.aidspan.org/gfo_article/global-fundtakes-steps-improve-Ifa-performance

24. Macro International. The Five-Year Evaluation of the Global Fund to Fight AIDS, Tuberculosis, and Malaria Synthesis of Study Areas 1, 2 and 3. 2009. Available from: http://www.theglobalfund. org/en/terg/evaluations/5year/

25. Ryan L. Evaluation of the Organizational Effectiveness of the Global Fund. Macro International Review Document [internet]. 2007. Available from: www.theglobalfund.org/documents/terg/ TERG_SA1_Report_en/

26. Kevany S. Global Health Diplomacy, 'Smart Power', and the New World Order. Glob Public Health 2014: 1-21. doi: 10.1080/17441692.2014.921219 